\title{
Defining institutions: taking history seriously
}

\begin{abstract}
This paper suggests an alternative list of institutions to that commonly encountered in the literature on institutional logics. This is done as a response to calls for greater clarity about basic terms. The resources of history are drawn upon to formulate the suggested candidates for the status of institution, with brief outlines for each of some key attributes. It is argued that the proposed specification would enhance the possibilities for comparative analysis.
\end{abstract}

\section{Keywords:}

Institutions; institutional logic; history 


\section{Defining institutions: taking history seriously}

Considerable progress has been made in elaborating the notion of institutional logics, both in specifying how they might operate and how that operation might be conditioned at different levels of activity. There is now a voluminous journal literature and a valuable book length summary of this progress (Thornton, Occasio and Lounsbury, 2012). But the nagging doubt remains: what are these institutions in which logics operate? There is a danger that the unexamined nature of this questions means that institutions become taken for granted, as in the following: 'At the societal level, scholars delineate seven distinct institutional orders and associated logics: family, community, religion, state, market, profession, and corporation' (Besharov and Smith, 2014: 365). This is taken directly from the Thornton, Occasio and Lounsbury text as if this were unproblematic but, as I hope to show, the basis for this list is by no means as clear as might be thought. This article seeks to address this question, by a return, via Friedland and Alford's seminal 1991 contribution, to Weber. I take institutions to be enduring combinations of material practices and symbolic constructions, relatively few in number, operating at the societal level and conditioning human activity. I propose to address the question of the definition of institutions by looking at history, not just as a source of evidence, but also as a conceptual resource, by looking at how historians have approached the topic. I show that this results in a different list of institutions which has consequences for how we view organizations.

I start by considering why this enterprise of definition is necessary, arguing that comparative analysis and questions of change require more clarity. I outline some of the broader resources that I draw upon, notably the recent work of Roger Friedland (2009) on the connection between logics and practice and the social theorist Margaret Archer and her advocacy of the 
necessity of analytical narratives of emergence (1995). This frames a consideration of some alternative approaches to the formulation of institutions, notably the comparative business systems perspective (Whitley, 1999) and the ‘orders of worth' proposed by Boltanski and Thevenot (2006). I give my reasons for preferring to act on a suggestion by Thornton, Occasio and Lounsbury (2012: 66) that Weber's discussion of value spheres might offer a promising line of inquiry. Using his formulation as a starting point, I consider a number of candidates for the status of institution, drawing on the work of historians. I argue for these candidates on the basis of their enduring status and their relation to some aspect of how humans have interacted with each other and the world and made sense of such interactions. Having done so, I discuss some of the struggles within the institutions I have identified, with special reference to particular conjunctions of time and space. I conclude by returning to the implications for our study of organizations, arguing that the approach essayed here enable us to maintain firmly a focus on institutions at the societal level that condition organizational activity.

\section{COMPETING PERSPECTIVES}

It could be argued that the search for definitions is a quixotic endeavour, condemned to failure. On a strong version of this argument, concepts need only to be contextualised to the situation at hand, with the argument for their validity being confined to their usefulness for analysis. A weaker version would recognise the need for more clarity, but prefer to hand it off to other disciplines and keep the notion of institution as a vague but helpful resource to be called upon as needed. As Greenwood et al (2008: 14) note 'Much like the early days of organization theory, when a tacit agreement occurred to stop attempting to define 'organization', there emerged an unwritten assumption that we intuitively know what we mean by institution and thus have no further need to define it'. They do, however, go on to suggest the need for the development of 'a more common vocabulary'. The danger of not 
having such a vocabulary is the snowballing of forms of logic, each adapted to a particular situation but with no common point of reference. Even more problematic is the tendency to relativise logics to a particular level, most notably that of the field. With that, the whole enterprise of Friedland and Alford (1991) of 'bringing society back in' is lost, with a focus on only those forces which directly impinge on economic activity. The danger, as I hope to show, is that this means neglecting broader changes in society that have profound implications for organizations and organizing.

However, this raises another concern, to do with the disciplinary division of labour. It might be conceded that this definitional enterprise is justified, but that it is not the province of organizational scholars; indeed, that it might divert such scholars from their primary focus (Kraatz and Block, 2008: 247). The point is well made, but experience suggests that, especially with the sheer volume of publications, that scholars tend to get trapped within their own discipline, not being able to lift their heads up to take in the broader picture (Suddaby et al, 2010: 1239). Intellectual endeavour, also, should not be a one way street, in which organizational scholars wait for the intellectual advances of their sociological colleagues. I draw in this article on what is perhaps a wider range of literature than usually encountered with the ambition of re-orienting the debate back towards some of the broader issues.

I start, however, with the summary of the development of institutional logics provided by Thornton, Occasio and Lounsbury (2012). This is in part because of its influence on the debate in this journal and elsewhere and in part because of an intriguing suggestion that is made in the course of their discussion of Friedland and Alford. They note that, to their surprise, Friedland and Alford did not reference aspects of Weber's work, notably his notion of value spheres. 'Weber,' Thornton et al note, ' identified several life-orders or what he termed value-spheres, for example the economic, political, esthetic, erotic, and intellectual spheres' (Thornton, Occasio and Lounsbury, 2012: 66). Friedland has returned to these 
distinctions in later work, which I discuss in due course, but this is a valuable suggestion which I return to later. For now, however, problems with the way institutions are defined necessitate a brief review and critique of the way Thornton et al arrive at their categories. This is because they, in turn, have some fairly pointed things to say about Friedland and Alford. For example, they point out that 'The influences of the professions, which both Meyer and Rowan (1977) and DiMaggio and Powell (1983) so clearly laid out, are mysteriously absent' (Thornton, Occasio and Lounsbury, 2012: 66). What, however, makes this 'mysterious'? There are clearly criteria for such a judgment being deployed, but they are not articulated. What this seems to rest on is the volume of published material, which I will argue is an insecure basis for judgment. The same could be said about the next observation, which is that 'Also absent is the institutional order of the corporation' (Thornton, Occasio and Lounsbury, 2012: 66). After all, it could be argued that the corporation is a historically specific organizational form, one which, while powerful in its time, is open to replacement by other forms (Davis, 2009). Finally, the observation is made that Thornton

further questioned the reasoning of qualifying the institutional order of the state as the "bureaucratic state". Isn't bureaucracy an organizational form used by the state to carry out its objectives. Couldn't other institutional orders be characterized as bureaucratic as well? (Thornton, Occasio and Lounsbury, 2012: 67).

That is a fair point, and it could be further argued that if we turn to the literature on the state that of rather more centrality is the notion of the 'nation state'. However, if we accept this point, then can we not turn the same argument back on the professions? Indeed Boltanski and Thevenot (2066: 292) seem to be making this point when they note that 'a person's profession, considered to be a fundamental attribute in a great number of situations, remains a passageway between worths and an object of tension'. That is, for them, profession is a crosscutting term which is deployed with different inflections in several of their 'orders of worth'. 
In other words, the status of the categories proposed by Thornton et al seems to be based on some unarticulated assumptions, one of which appears to be the sheer volume of work emanating from the organizational literature. These seem to be shaky foundations for considering societal level institutions where, arguably, the need is to work from the 'outside' in rather than the reverse.

For this reason, I wish to go back to Friedland and Alford, and beyond them to Weber, but first I need to consider some alternative approaches, two of which place institutions firmly at the level of society. The field of institutional economics, largely based on the work of Douglas North, operates with a clear notion of institutions at a supra-organizational level (Hall and Soskice, 2001: 9). However, it operates on a view of institutions as repairing market imperfections, tending to a view of institutions as the regulations which condition economic activity. A more socially aware model, but one which still has economic activity as its prime focus, is the comparative business systems tradition (Whitley, 2000). This seeks to identify clusters of inter-connected institutions that shape economic activity. Such clusters are associated with zones of economic activity which might cross state boundaries. The institutions which are focused on are 'the state, the financial, educational and training systems, the labour market regime and norms and values governing trust and authority relationships' (Djelic and Quack, 2008: 304). What is valuable in this approach is the specification of institutions at a level of generality such that they are not bounded by one particular location, something which can be a concern in much of the work on institutional logics. However, the status of culture in this approach is something of a residual term.

The second alternative is that presented by Boltanski and Thevenot (2006) in their work on justification. This proposes a number of 'orders of worth' and has been influential in the French school examining the sociology of conventions (Cloutier and Langley, 2013). They propose a number of such orders of worth or 'worlds: these are inspired, domestic, fame, 
civic, market, and industrial. They suggest that each is drawn upon when persons justify their actions, giving them a sense of worth and identity. There are some suggestive elements to this, but there are also critiques to do with the derivation of these orders. For the purpose of this article, however, it is sufficient to recognise, as the authors do, that 'The model of justification we have presented here in its broad outlines does not claim to account for the behavior of actors in any and all situations they may encounter' (Boltanski and Thevenot, 2006: 347). Importantly, they note that

The act of bypassing justice and behaving only as one pleases, without being burdened by the requirement to explain, is the defining act of violence. But by the same token, such acts fall outside the scope of our research (Boltanski and Thevenot, 2006: 37).

I will argue that this means that this excludes considerable of an important institution, that of the military. Because of this, I focus on the suggestions made by Friedland and Alford (1991).

A starting point is to return to the emphasis in Friedland and Alford (1991) on their advocacy of a model of institutional spheres, each with their own logics and possessing relative autonomy. This is important as presenting an alternative to more materialist interpretations of society drawing on interpretations of Marxism which operated on a widely discredited model of base and superstructure. In this, cultural constructions were built on a material base and, in the crudest forms, were simply a mirror of material interests. Friedland and Alford (1991) were anxious to preserve autonomy for their institutional spheres, whilst recognising interconnections. It is also important to remember, in the context of our earlier discussion, that this was a view from outside the world of organizational studies, indeed one in which religion and the lessons derived from its study were of considerable importance. This is why the 
professions and the corporation were not included; from an 'external' vantage point they were simply not significant enough. In this regard, Friedland and Alford (1991) were consistent with major currents in social theory. One which provides some of the broader conceptual resources on which this article is based is the work of Margaret Archer (1995). Her realist social theory, based on the resources of critical realism, is an extensive body of work; for the present purpose what is important is her focus on emergence and the importance of history. Society is activity dependent, but once emergent from activity, both structure and culture escape their conditions of production and become the context in which agents develop their projects. The combination of these emergent structural and cultural properties forms situational logics which shape but do not determine conduct. Because of this focus on emergence and history, Archer advocates the construction of what she terms 'analytical narratives of emergence'. As an example, she refers to the work of Norbert Elias on the emergence of norms of 'civilised' conduct over centuries. Her own comparative work on educational systems covered four countries over some 600 years (Archer, 1979). That provides the orientation to history that is developed below.

Roger Friedland has also developed his ideas, in part through a turn to precisely that aspect of Weber's work that was noted as being passed over above. He has also developed a view of the internal life of institutions, drawing on an Aristotelian notion of substance. Derived from this he suggests that an institutional logic is "a bundle of practices organized around a particular substance and its secondary derivatives from which the normativity of those practices is derived" (Friedland, 2009: 61). Further, those practices are central to the creation and maintenance of substance, which cannot be directly observed but which is "immanent in the practices that organize an institutional field, values never exhausted by those practices, practices premised on faith" (Friedland, 2009: 61). This is the warrant for returning to Weber, to see if in his value spheres we can reformulate our notions of what constitutes institutions. 
Weber's essay on 'religious rejections of the world and their directions', first published in 1915 , took as its starting point Indian religious forms, the most developed form, he argued, of religion rejecting the world (Gerth and Mills, 1948). In order to do this, he suggested a number of ideal types of 'life orders' against which to contrast the claims of religion. These value spheres consisted of different ways of being in the world and Weber considered them in turn to explore the tensions between them and religion. These spheres of value were: kinship; economic; political; aesthetic; erotic and intellectual. Interestingly, in another essay published in the same collection, an extract from Economy and Society, our attention is drawn to the importance of the military in providing the template for the wider importance of discipline in the modern world. If we turn to the work of a historian whose work we will draw upon in more detail below, the Dutch art historian Jacob Huizinga, we can see an echo of these categories when he comments that 'while in the more highly organized forms of society religion, science, law, war and politics gradually lose touch with play, the function of the poet still remains fixed in the play-sphere where it was born' (Huizinga, 1949: 119). We see that for a cultural historian war was an important category, as was another missing from Weber's list, that of law. This gives us a list of nine potential institutions to examine, all of which, it will be contended, involve some aspect of humans interacting with each other or their world and seeking to make sense of it. Before turning to these, however, some brief words on history and historians are in order.

'History' can have a dual sense; it is about both the past and about how historians have presented that past (Rowlinson, Hassard and Decker, 2014). History here is seen in the sense of what Bergson terms 'duration', 'the continuous progress of the past which gnaws into the future and which swells as it advances' (Bergson, 1960: 5). This is not time as a variable, but history as irreversible. Of course, historians have their different interpretations of that past. 
They are notoriously resistant to theorizing their categories, rather building them into the very fabric of the narratives they construct. (An exception is William Sewell (2005), whose Logics of History, especially through his engagement with Giddens' structuration theory, has been influential in broader debates in social theory). This means that a historian like Huizinga will tend to simply assume the status of the concepts that he outlines in the quotation given above. But the work of such historians is incredibly valuable in indicating what is durable over large swathes of time, so providing us with an alternative to the ways in which institutions have been rather assumed in the existing literature. I now turn to examine each of the spheres of value that I outlined above, looking at both the light that history can shed on them and how we might need to modify them to come up with a set of institutions for the analysis of contemporary organizations. I examine them in the order that Weber attended to them with some slight modifications that will be explained as I progress. I conclude with two that were not covered in his engagement with religious rejections of the world. I cannot pretend here the reach of a Weber or a Huizinga. In particular, I need to recognise at this stage that the histories I draw upon tend to a focus on the West, on Europe and, within that, on the UK. That is because as a working historian my focus has been on those areas. In addition, as will be seen, sources which pay close attention to practices as understood here are often difficult to come by. The discussion is, therefore, provisional, tentative and corrigible. However, the attempt seems worth risking in order to push the debate forward.

\section{INSTITUTIONS OUTLINED}

\section{'My God': religion}

There are a number of reasons for starting this discussion with religion. Its continuing importance in the world, despite the claims for secularisation, would by itself merit greater attention than perhaps is evident in the organizational literature. It was clearly Weber's 
starting point and not only because of its social prominence. It was because it not only left its traces even when belief had waned, as we will see, but because the spirit of religion, in the words 'faith' and 'belief', animated the other spheres. That is, as Friedland points out, even in the most 'rational' of enterprises there is a core of belief in an animating principle. 'For Weber,' he argues, 'institutions are religious in the sense that they bind their adherents through faith, sacrifice, and passion' (Friedland, 2014: 219). However, what historical studies also indicate is the way in which large areas of what are now predominantly secular activities have been carved out of religion. This is particularly the case, as we will explore below, with law and learning.

In his broader consideration of world religions, Weber considered five: Confucianism, Hinduism, Buddhism, Christianity and Islam. To this list he also added consideration of Judaism. To consider such a range of religions across space and time demanded a formidable range of knowledge. It meant that Weber's focus was often on belief as expressed in programmatic statements. Indeed, for one commentator on his work 'in all social phenomena it is the non-everyday that interests him, that which bursts through everyday life.' (Hennis, 1988: 181). However, particularly under the influence of Foucault, it is possible for historians to focus on just that importance of the everyday to the sustaining of institutional logics. Philip Gorski (2003), for example, has pushed back the origins of the 'disciplinary revolution' to seventeenth century Netherlands, arguing that Reformed Protestantism necessitated particular practices in order to be able to function, practices which could subsequently form templates for activities in other domains. There are actually hints of such a focus in Weber's work on sects where, for example, he considers the organizational implications of closed communion (Gerth and Mills, 1948: 312). This was where the central sacrament of communion was only available to those confirmed as worthy to receive it, which required tests of worthiness and means of recording it (Schmidt, 2001). Such means, elaborated in particular in Scottish 
Presbyterianism, then formed taken for granted principles of organizing which translated into other places, notably the USA of the eighteenth and nineteenth centuries.

This focus on religion as a social practice is made especially vivid because of the character of religious practice as ritual. Students of such rituals in the European Middle Ages have argued that it is misleading to 'read off' rituals from formal programmatic statements (Clark, 2004: 126). Rituals take on their power not from any shared agreement on theological statements but from their performance, out of which a shared sense of belief emerges (Whitehouse, 2004: 93). In more contemporary terms, this is the 'doing church' of Creed, DeJordy and Lok's (2010) Protestant adherents in the USA. In turn, such shared activities become a powerful sense of identity. Thus Baltzell recounts the story of an eminent Boston Unitarian commenting to an Episcopalian friend, 'Eliza, do you kneel down in church and call yourself a miserable sinner? Neither I nor any member of my family will ever do that!' (emphasis in original) (Baltzell, 1979: 367).

What we see historically is a progressive 'carving out' of new value spheres from religion, although often leaving its traces in these spheres. This is particularly the case where practices originally animated by belief become detached from that belief and are accepted as the taken for granted ways of carrying out activities. Thus the 'culture of organization' which Peter Hall (1998) sees as characterizing the post-bellum United States with its origins in varieties of Protestantism and Judaism, which contributes to the rise of corporations. Thus also the enduring tension between value spheres, animated by belief in its central substance.

\section{'What's love got to do with it?' The family}

For Weber, 'the first power with which [religious communities] have come into conflict has been the natural sib' (Gerth and Mills, 1948: 328-9). This is because the new community demands the full commitment and adherence of its believers, forcing them to break the ties of 
kinship and replicate them with their new 'family'. There are strong parallels in this focus on kinship with the 'domestic world' of Boltanski and Thevenot (2006), in which the markers of worth are words such as 'respect', 'honour' and 'reputation'. This focus on hierarchical ordering does seem in large measure to reflect the particular source they use (a manual with a strong stress on etiquette) and it does not feature the animating power of love. Weber separates this out under the particular heading of erotic love. This is because of its sharp tension with the ecstatic belief of other worldly religion. For our purposes, however, it seems better to think of the family as the institutional sphere with love as its animating purpose. Families, of course, comprise more than love, more indeed than honour; they can also be sites of violence and humiliation. But if we consider institutions in Friedland's (2009) terms as a bundle of practices animated by a central substance, then love, certainly as an ideal, seems the appropriate candidate.

What historians would suggest is the evolving nature of this central substance accompanied by changes in practices. We see first the emergence of courtly love, available only to the nobility of Europe but then generalised to an ideal of romantic love through the efforts of poets and playwrights. All the time this is in tension with the demands of kinship, but, certainly in large parts of the West, the ideal of companionate love came to represent the key animating factor. During this process practices such as marriage underwent considerable changes in content but retained their essential character. Despite the concerns of a thinker like Foucault (1997), excluded groups have not developed alternative practices but have, by and large, clamoured for inclusion under the old rubric. The resilience of the family as an institution seems to suggest something of a cautionary tale about the use of a term like 'institutional change'. While practices might change over relatively short periods, the institution itself may prove much more impervious to change. In some parts of the world, for example, the practice of marriage has been rejected by other groups, often in ever larger 
numbers, but the family with its relatively enduring commitments seems to answer certain human needs. At least no powerful alternative to what seem to be characteristic needs for companionship and connection seems to have emerged.

The family is the institution in which the relationship between the substance and the practices seems at its most immediate, relatively unmediated by other forms, such as organizations, which are proper to the institutional sphere itself. There are plenty of such forces from other institutional spheres seeking to mould the family, from law courts to church bodies, each claiming and contesting jurisdiction. But it seems misleading to conceive of the family itself as an organization. One could argue that under certain arrangements the household is a form of organization, especially when it contains unrelated members, such as servants. This is clearest in farming environments, where the family farm is at once an economic unit and the site for the production of family practices. But even here there seems a secular trend towards such organizational forms converging with those in other spheres, notably the economy. So it is better to speak of the family inflecting those organizational forms, such as in the family firm, rather than treating such forms as proper to the institutional sphere of the family.

\section{'Money, money, money': the economy}

What to say of the economy? It is the core of the institutionalist project that not only are there cultural forces at work in society that overflow the rational calculations said to be indicative of economic activity, but that economic activity itself is profoundly shaped by culture. The rationality of economic life, that is, is as much an artefact of the search for order by economists, themselves shaped by powerful myths, as it is a natural property of economic life itself. At the heart, just as with the other institutions, is belief. Taylor has argued that in Smith's work, God becomes secularized: 'God did not simply disappear but was reborn as the market' (Taylor, 2004: 6). The market then becomes the object of faith, in which practices, 
such as the granting of credit, take their efficacy from a belief in shared rationalized myths.

This for Taylor then becomes a 'confidence game' in which economic activity is based not on real world production but on belief in future states guided by forms of belief. One can see something similar in Mackenzie's sociological work on the way in which economic theories of practices such as hedging and derivatives are not simple mirrors of a pre-existing reality but actually bring that reality into existence. At the heart, to take Taylor's argument, is an essentially theological position, in which the animating belief is something like 'growth', the faith that gain can be achieved.

\section{Politics}

Adam Smith can be seen as one of the foundations of a whole tradition of political economy. Boltanski and Thevenot (2006) base their arguments about the importance of spheres of worth on an extended discussion of the relationship between Smith moral philosophy and his economic theory, something which has been a matter of enduring debate. From this, in part, they derive their notion of the 'civic world', one in which the 'general interest' is the animating force. One sees in this the influence of French secular republicanism, a particular form of the nation state which was a defining feature of political theory and practice for centuries and which retains, in the face of globalisation, considerable power as a source of identity and worth. This can be seen as a particular form of 'imagined community' in the influential formation of Benedict Anderson (1991). 'Imagined' here does not mean 'imaginary'. It is rather a reference to those myths and symbols which form a basis for identity with others who may never be known. In this sense it can be seen to encompass the focus on communities in Thornton et al's treatment, but to operate at different scales. It draws our attention to those practices, especially those embodied in 'traditions', which sustain such senses of community. 
Traditions are placed in scare quotes to reflect the degree to which historians have explored the way in which they can be invented. Traditions, by their nature, are of ancient origin, with origin myths shrouded in the clouds of antiquity. On closer examination, however, traditions have been shown by historians to be creations of much more recent origin, often of deliberate instigation. In a seminal collection, a number of historians focussed on such creations showing, for example, that the tartan which lies at the heart of powerful images of Scottish identity, especially in modern brand management, is a creation of the early nineteenth century, owing much to the imaginative efforts of the novelist Sir Walter Scott (Hobsbawm and Ranger, 1992). In turn, this has spawned 'traditions', such as the 'kirking of the tartan' at 'Highland Games' in the United States which were never seen in their supposed place of origin (Devine, 2012: 281). Of course, once emergent, such traditions can gain a life of their own and so deserve serious analysis for their effects, but history is a powerful means to debunk some of the more preposterous claims.

\section{'Dancin' in the streets': play and aesthetics}

I turn now to perhaps my most surprising and provocative suggestion, but one which I hope to show is embedded both in historical accounts and in contemporary life: the notion of 'play' as a central institution, with its animating principle one of 'fun'. Weber's focus was on aesthetics but I seek to broaden this by drawing on the work of the Dutch art historian Johan Huizinga (1948). His work is fascinating in proposing play as an elemental component of civilization, one whose place he articulated in contrast and relation to a number of other categories: law, war, knowing, religion, poetry, philosophy and art. It can be seen that this list has striking parallels with the lists that we have examined so far, especially with that of Weber. Huizinga has interesting things to say in each connection, but for the current purpose I want to focus on the creation of a single category which has some form of creative representation of human existence at its core. For Huizinga, there were considerable 
connections between some forms of artistic expression and play. Dancing, for example, 'is a particular and particularly perfect form of playing' (Huizinga, 1948: 165). However, his concerns, just as those of Weber, are marked by their time and place. This led to a focus on 'high art' and the deploring of what for them, were, dangerous modern trends. Thus

The supersession of the round dance, choral and figure dances by dancing a deux, whether this take the form of gyrating as in the waltz or polka or the slitherings and slidings and even acrobatics of contemporary dancing, is probably to be regarded as a symptom of declining culture (Huizinga, 1948: 164).

What we have become more conscious of, and more tolerant of (if not more celebratory of), is the full range of what we term 'culture'. It is interesting to note that Boltanski, together with another collaborator, Eve Chiapello, has argued for a 'new spirit of capitalism' (Boltanski and Ciapello, 2007). Once again drawing on management texts for its corpus of evidence, this suggests that the legacy of 1968 has been a freer form of management which challenges top down notions of command and control. It is surprising here that, apart from a passing mention, they fail to focus on popular music as a key carrier for such ideas (Parker, 2008).

Huizinga, writing in the 1940s, was sceptical about the role of play in modern society. For him, 'the sad conclusion forces itself upon us that the play-element in culture has been on the wane ever since the 18th century, when it was in full flower' (Huizinga, 1948: 2069). He saw developments such as the rise of organized sport as false play, because it was taken too seriously. An interesting suggestion made almost as an aside was 'Business becomes play. This process goes so far that some of the great business concerns deliberately instil the playspirit into their workers so as to step up production. The trend is now reversed: play becomes business' (Huizinga, 1948: 165). But if we take his focus seriously then it draws our attention 
to the ways in which many areas of economic activity play is re-entering the workplace. From hi-tech offices to residential courses, play is promoted as a way of both attracting knowledge workers and of changing the nature of work. Figure 1 shows how this spirit is manifest in the most unlikely of places, where organizational announcements which once would have been couched in legalistic language are now expressed in a playful spirit. We can be sceptical about the 'true' level of fun that is expressed in such pronouncements, but it perhaps indicates to us the wider place of play in contemporary society. After all, it cannot be said that in the pursuit of fun there are not significant practices and specific organizational forms, from art galleries to symphony orchestras, from jazz bands to music festivals, several of which have featured in influential new institutionalist accounts.

Insert figure 1 about here

\section{'Knowing you, knowing me': science and education}

The final value sphere that Weber considered was what he termed the 'intellectual' one; we noted above that knowing and philosophy were cardinal reference points for Huizinga as well. It is therefore mysterious, to use Thornton et al's word, why this sphere has not featured in accounts of institutional logics more prominently. After all, most of those who write on the topic hail from what are termed, in another discourse, 'institutions', and confront in their working activities questions of the boundaries between their world and those of the 'real' world (as in the debate on relevance). In addition, for some, such as John Meyer (2008), the spread and development of higher education is a key element in the rationalization of the 
modern world. It is also the domain which illustrates most clearly the carving out of significant areas of activity from the purview of religion. Indeed, this heritage is what gives added spice to the debates between science and religion. Ways of knowing the world, and their associated educational arrangements, start with control by a priesthood. As Weber notes

The priesthood, as the only agents capable of conserving tradition, took over the training of youth in the law and often in purely administrative technologies, and, above all, in writing and calculus. The more religion became book-religion and doctrine, the more literary it became and the more efficacious it was in provoking rational lay-thinking, freed of priestly control (Gerth and Mills, 351).

From this emerged the universities, firstly as specialist centres of theological training and then as broader centres. In some places, such as England, this religious function continued to colour the university curriculum for centuries; in others, such as Scotland, areas of more practical application such as medicine and geology appeared much sooner (Carter, 1990). We could argue here about what the appropriate word is for the animating substance, but I wish to settle on 'curiosity' as an animating principle which colours knowing practices across a range of disciplines.

\section{'War! What is it good for?': the military}

It is perhaps surprising that the military is not seen as a significant institution given its centrality in many of the practices and metaphors that permeate organizational life, notably the concept of strategy. It would seem to possess distinctive practices and organizational forms, together with a belief in values which often set its practitioners off from civilian life. Its centrality in the development of what we come to term modern life is stressed by Anthony Giddens (1990). He argues, in a discussion of what he terms 'the institutional dimensions of modernity' that there were four inter-linked factors in the rise of modernity: surveillance (the 
growth of the state apparatus); capitalism; industrialism (which he takes to be the transformation of nature); and military power (Giddens, 1990: 55-63). Here there was a crucial link with the rise of the state, which developed a distinctive monopoly of the means of violence within particular boundaries. Although linked, however, the military develops distinctive practices of its own which are seen to separate it from the civilian world. Indeed, some of those practices, such as intensive drilling, have precisely the purpose of engendering such a separation, taking their meaning from a military logic. That logic might be expressed in a number of words - courage, reputation, glory, loyalty, are all candidates - but honour seems to express best this animating principle.

\section{'I fought the law' - the rule of law}

Finally, we come to a value sphere which Weber does not mention but which is surely central to his work on bureaucracy and rationalization. Interestingly, it is also a sphere where the work of an eminent historian provides us with support for the overall approach essayed here.

The historian was E. P, Thompson, a leading British Marxist historian, but one implacably opposed to structuralist versions of Marxism, especially those operating with a conceptualisation of base and superstructure. This background and this opposition meant that he was more willing than many historians to elaborate his theoretical presuppositions. When he does so in his great book Whigs and Hunters it is illuminating for the general argument pursued here (Thompson, 1977). Thompson's book is a study of the 'Black Act' of 1723, a vicious piece of class-based legislation which introduced a massive number of offences punishable by capital punishment. However, Thompson's argument is that it is wrong to see law as just a reflection of class interests, for it had 'its own characteristics, its own independent history and logic of evolution'(Thompson, 1977: 262). As he expressed it, as well as at times being permeated with particular instances of power, 
The law may also be seen as ideology, or as particular rules and sanctions which stand in a definite and active relationship (often a field of conflict) to social norms; and, finally, it may be seen simply in terms of its own logic, rules and procedures - that is, simply as law. And it is not possible to conceive of any complex society without law (Thompson, 1977, 260).

This nicely encapsulates some of the arguments that have been at the heart of this article. The major institutional spheres have their own logics, expressed in practices which take their meaning from ultimate commitments - justice, in the case of the law. That such practices imperfectly realise that commitment does not detract from it as an animating principle. Such practices create forms which are proper to that sphere. This bundle of practices and an animating substance endure because they express some sort of need arising from the interactions of humans with each other, with the natural world and with the search for meaning.

\section{DISCUSSION}

The institutions that have been sketched in here, with suggestions about their animating principle, their distinctive organizations and practices, are summarized in table 1.

Insert table 1 about here

Table 1 represents only the barest of summaries of the discussion. Selecting a word to represent substances which are often multi-faceted is challenging; organizations and practices 
are indicative only and would merit much more elaboration. The discussion of each institution has, of necessity, to be brief; in this section I consider some general questions which span them all. I consider their mobility across time and space. I discuss contradictions and compromises both within and between institutions. I return to the discussion about institutional change. And I consider candidates for the status of institutions which arise from this discussion.

One concern with much of the work in new institutionalism is that it appears bound to phenomena that are typical of the global north, especially the USA. That debate happens in other spheres as well. The validity of the application of a concept like 'religion' has been brought into question when detached from what are seen to be its origins in the consideration of western religions (Asad, 1993). This remains an open debate, but one consequence is the need to specify the concept at a level of abstraction which makes it transferable across time and space. Thus an important review defines religion as 'any mythically sustained concern for ultimate meanings coupled with a ritually reinforced sense of social belonging' (Demerath and Schmidt, 1998: 382). Of course, such a conceptualization is also potentially transferable, as Friedland suggests, to other institutional spheres. The idea of the outline in table one is that the spheres are potentially applicable across a range of temporally and spatially situated activities. Of course, the balance of each will be different and there is nothing in this formulation that suggests the primacy of any of them. In eighteenth century England, for example, Thompson suggests that

the hegemony of the eighteenth century gentry and aristocracy was expressed, above all, not in military force, not in the mystifications of a priesthood or of the press, not even in economic coercion, but in the rituals of the study of the Justices of the Peace, in the quarter-sessions, in the pomp of the Assizes and in the theatre of Tyburn (Thompson, 1977: 262). ${ }^{1}$ 
Thus it follows that any analysis has to consider the specificity of each institutional sphere in a particular time and place. To return to our focus on religion, Weber's analysis of the relationship between religion and the economy covered, as we have seen, the major world religions. These had very different inflections, and these inflections changed over time. To take the example of lending at interest, Christianity developed a position of opposition in the Middle Ages but this shifted over the sixteenth and seventeenth centuries in different paces under the influence of different strains of Reformed Protestantism (Munro, 2011).

Meanwhile, Islam continued its opposition, developing its own distinctive practices of lending money. However, much of the analysis of these changes rests at the level of formal statements of theological belief (Ali, 2005). If the conception of institutions put forward here has any purchase, then equal attention needs to be paid to the concomitant practices. This presents something of a research agenda.

To continue with our example of religion for illustrative purposes, we can see that it generates distinctive forms of organization which mediate the relationship between substance and practice. The church is a way of organizing religious practice which is particularly associated with Christianity, but even here there are considerable differences in form, from the centralized control and hierarchy of Roman Catholicism to the local control of Congregationalism (Jeremy, 1998). This reminds us that there can be tensions and contradictions within specific instantiations of an overall institution. So not only are there different conceptions of what faith is taken to be between religions such as Christianity, Judaism and Islam, for example, but each tradition is itself internally divided. This points to the need to be specific about how a substance like 'faith' is interpreted and mobilised. The outline presented, that is, can only be a broad sketch which needs to be populated for specific instances. It has been my contention that history is vital to this act of population. 
What history also points to is the enduring nature of institutions in a way which should give us pause in using the phrase 'institutional change'. If we conceptualise institutions as being enduring in the way that historians envisage them, then such change happens but slowly and over long periods of time. This means that we need to be careful in seeing fields and organizations as mediators for the impact of institutions. Over time, changes in practice can shift logics at the level of the field, as carefully traced in the legal sphere by Smets, Morris and Greenwood (2012). In time, such changes may shift the meaning of the central institution, but this is likely to be over a much longer timescale and involve collective actors.

I have suggested that the institutions I have outlined are ones which an examination of history shows are enduring facets of human existence, giving meaning to our interactions with each other and the natural world. That formulation might also suggest some other candidates for the status of institutions, which are offered here as speculations and invitations to debate. One might be seen as an enduring aspect of the human condition, the other as a more emergent institution. Both are concerned with our relation to the natural world. Given the embodied nature of human existence with its susceptibility to aging and disease, then a concern with ameliorating those susceptibilities might be thought to give rise to a medical logic. Medicine certainly has its distinctive practices, such as operations and its distinctive forms of organization, such as hospitals. Through its Hippocratic Oath it also has a statement of the values that lie at its heart, often ones which bring its practitioners into conflict with other value spheres. Whether this is sufficient to constitute it as an institutional sphere would require an account of its history that I am not familiar with. It could be argued that, while operating with specialised practices, that these are too sealed off from other aspects of life to constitute them as a meaning system which can then shape activities in other domains. A more hidden institution, and one which may have emergent candidate status, is that generated by our engagement with the natural world. We have noted that Giddens uses the rather 
misleading term 'industrialisation' to express this relationship. He uses this to cover the creation of environments through technological innovation. He contrasted this to a premodern world in which 'humans mostly saw themselves as continuous with nature' (Giddens, 1990: 56). Industrialization, in these terms, operated with a logic of the environment as a resource, something to be exploited. If there were foundations for this notion, they were probably supplied principally by Christianity, especially in its Protestant varieties. However, growing awareness of environmental degradation perhaps fosters a return to those traditions which promote an alternative logic of relationships with the natural world, one which focuses on resource conservation. Thinking about the environment as an institution, albeit an emerging one with developing practices, might be one way

\section{CONCLUSION}

We have noted that some organizations are specialised to particular institutions, but it is more likely that organizations stand at the confluence of number of competing value spheres (Kraatz and Block, 2008). And certainly, organizational members are likely to have been formed in different value spheres, giving rise to both tensions and to possibilities for innovation. The outline definition of institutions here, based on the ways in which historians have used the concept and have provided evidence for the ways in which institutions change and conflict over time, has been presented in order to address some of the concerns about conceptual clarity presented at the beginning of the article. In suggesting that institutions are responses to enduring relationships between humans and between humans and the natural world of which they are a part, I use the resources of history to resist any accusations of essentialism. While I suggest that there are enduring features of the human condition which do indeed rest on capacities which seem constitutive of human existence, notably the capacity to alter the environment and the capacity for language (which in turn fosters 
conceptualizations of that environment), history indicates to us the plasticity of arrangements which can be generated by these capacities (O’Mahoney, 2012).

Does attention to these factors draw our attention away from the analysis of organizations? Is an attempt to define institutions in this manner a transgression of disciplinary boundaries? It may be, but the argument of this article is that it is necessary from time to time to lift our head up from the 'blooming, buzzing confusion' of our own literature and look afresh at how others conceptualize the core issues. I have drawn upon a range of material which is probably unfamiliar to many readers of this journal, but there are remarkable echoes in the work of historians of some of the matters that concern us most.

\section{REFERENCES}

Ali, Abbas. (2005) Islamic Perspectives on Management and Organization, Cheltenham: Edward Elgar.

Anderson, Benedict. (1991) Imagined Communities, London: Verso.

Archer, Margaret. (1979) Social Origins of Educational Systems, London: Sage.

Archer, Margaret. (1995) Realist Social Theory: The Morphogenetic Approach, Cambridge: Cambridge University Press.

Asad, Talal. (1993) Genealogies of Religion: Discipline and Reasons of Power in Christianity and Islam, Baltimore: John Hopkins University Press.

Baltzell, E. (1979) Puritan Boston and Quaker Philadelphia: Two Protestant Ethics and the Spirit of Class Authority and Leadership, New York: Free Press.

Bergson, Henri. (1960) Creative Evolution, London: Macmillan. 
Besharov, Marya and Smith, Wendy (2014) 'Multiple Institutional Logics in Organizations: Explaining Their Varied Nature and Implications', Academy of Management Review, 39(3) 364-381.

Boltanski, Luc and Thevenot, Laurent. (2006) On Justification: Economies of Worth, Princeton: Princeton University Press.

Boltanski, Luc and Chiapello, Eve. (2007) The New Spirit of Capitalism, London: Verso.

Carter, Ian. (1990) Ancient Cultures of Concei:. British University Fiction in the Post-War Years, London: Routledge.

Clark, Anne. (2004) 'Testing the Two Modes Theory: Christian Practice in the Later Middle Ages', in Whitehouse, H. \& Martin, L. (eds) Theorizing Religions Past: Archaeology, History, and Cognition, Walnut Creek CA: AltaMira Press 125-142.

Cloutier, Charlotte and Langley, Ann. (2013) 'The Logic of Institutional Logics: Insights From French Pragmatist Sociology', Journal of Management Inquiry, 22(4) 360-380.

Creed, Douglas, DeJordy, Rich and Lok, Jaco (2010) 'Being the change: resolving institutional contradiction through identity work', Academy of Management Journal, 53(6) 1336-1364.

Davis, Gerald. (2009) Managed by the Markets: How Finance Re-Shaped America, New York: Oxford University Press.

Demerath, N., Hall, Peter, Schmit, Terry and Williams, Rhys. (1998) Sacred Companies: Organizational Aspects of Religion and Religious Aspects of Organizations, New York: Oxford University Press. 
Demerath, N and Schmitt, Terry. (1998) 'Transcending Sacred and Secular: Mutual Benefits in Analyzing Religious and Nonreligious Organizations', in Demerath et al (eds) Sacred Companies, New York: Oxford University Press 381-392.

Devine, Tom. (2012) To the Ends of the Earth: Scotland's Global Diaspora, 1750-2010, London: Penguin.

Djelic, Marie-Laure and Quack, Sigrid. (2008) 'Institutions and Transnationalization', in R. Greenwood et al (Eds.) Sage Handbook of Organizational Institutionalism, London: Sage 299-323.

Foucault, Michel. (1997) Ethics, Subjectivity and Truth, (ed. Paul Rabinow, vol 1 of essential works), New York: The New Press.

Friedland, Roger and Alford, Robert. (1991) 'Bringing Society Back in: Symbols, Practices, and Institutional Contradictions', in W. Powell and P. DiMaggio (eds) The New Institutionalism in Organizational Analysis, Chicago: University of Chicago Press 232-266.

Friedland, Roger. (2009) 'Institution, Practice and Ontology: Towards A Religious Sociology', Research in the Sociology of Organizations, 27 45-83.

Friedland, Roger. (2014) 'Divine Institution: Max Weber's Value Spheres and Institutional Theory', Research in the Sociology of Organizations, 41 217-258.

Gerth, H and Mills, C. (1948) From Max Weber: Essays in Sociology, London: Routledge \& Kegan Paul.

Giddens, Anthony. (1990) The Consequences of Modernity, Cambridge: Polity. 
Gorski, Philip. (2003) The Disciplinary Revolution: Calvinism and the Rise of the State in Early Modern Europe, Chicago: University of Chicago Press.

Greenwood, Royston, Oliver, Christine, Suddaby, Roy and Sahlin-Anderson, Kerstin. (2008) 'Introduction', in R. Greenwood et al (Eds.) Sage Handbook of Organizational Institutionalism, London: Sage 1-46.

Greenwood, Royston, Oliver, Christine, Suddaby, Roy and Sahlin-Anderson, Kerstin. (2008) The SAGE Handbook of Organizational Institutionalism, London: Sage.

Hall, Peter and Soskice, David. (2001) Varieties of Capitalism: The Institutional Foundations of Comparative Advantage, Oxford: Oxford University Press.

Hall, Peter. (1998), 'Religion and the Organizational Revolution in the United States', in N. Demerath et al, Sacred Companies, pp. 99-115.

Hennis, Wilhelm. (1988) Max Weber, Essays in Reconstruction, London: Allen \& Unwin.

Hobsbawm, Eric and Ranger, Terence. (1992) The Invention of Tradition, Cambridge: Cambridge University Press.

Huizinga, Jacob. (1949) Homo Ludens: A Study of the Play-Element in Culture, London: Routledge \& Kegan Paul.

Jeremy, David. (1988) 'Important Questions about Business and Religion in Modern Britain', in David Jeremy (ed) Business and Religion in Britain, London: Gower 1-26.

Kraatz, Matthew and Block, Emily. (2008) 'Organizational Implications of Institutional Pluralism', in R. Greenwood et al (Eds.) Sage Handbook of Organizational Institutionalism, London: Sage 243-275. 
Meyer, John. (2008) 'Reflections on Institutional Theories of Organizations', in R. Greenwood et al (Eds.) Sage Handbook of Organizational Institutionalism, London: Sage 780-811.

Munro, John. (2011) Usury, Calvinism and credit in Protestant England: From the Sixteenth Century to the Industrial Revolution, University of Toronto: Department of Economics, Working Paper 439.

O'Mahoney, Joe. (2012) 'Embracing Essentialism: A Realist Critique of Resistance to Discursive Power', Organization, 19(6) 723-741.

Parker, Martin. (2008) 'The Seventh City: Review of Boltanski and Chiapello', Organization, 15(4) 610-620.

Rowlinson, Michael, Hassard, John and Decker, Stephanie. (2014) 'Strategies for Organizational History: A Dialogue between Historical Theory and Organization Theory', Academy of Management Review,.

Schmidt, Leigh. (2001) Holy Fairs: Scotland and the Making of American Revivalism, Grand Rapids, MI: Eerdmans Publishing Co.

Sewell, William. (2005) Logics of History: Social Theory and Social Transformation, Chicago: University of Chicago Press.

Smets, Michael, Morris, Tim and Greenwood, Royston. (2012) 'From Practice to Field: A Multilevel Model of Practice-Driven Institutional Change', Academy of Management Journal, 55(4), 877-904. 
Spicer, Andre and Sewell, Graham. (2010) 'From National Service to Global Player: Transforming the Organizational Logic of a Public Broadcaster', Journal of Management Studies, 47(6), 913-943.

Suddaby, Roy, Elsbach, Kimberly, Greenwood, Royston, Meyer, John and Zilber, Tammar. (2010) 'Organizations and their Institutional Environments - Bringing Meaning, Values, and Culture Back in', Academy of Management Journal, 53(6) 1234-1240.

Taylor, Mark. (2004) Confidence Games: Money and Markets in a World without Redemption, Chicago: University of Chicago Press.

Thompson, E. (1977) Whigs and Hunters: The Origin of the Black Act, London: Penguin.

Thornton, Patricia, Occasio, William, and Lounsbury, Michael. (2012) The Institutional Logics Perspective: A New Approach to Culture, Structure, and Process, Oxford: Oxford University Press.

Whitley, Richard. (2000) Divergent Capitalisms: The Social Structuring and Change of Business Systems, Oxford: Oxford University Press. 
Table 1: institutions and their attributes

\begin{tabular}{|l|l|l|l|}
\hline Institution & Substance & Organization & Practice \\
\hline Religion & Faith & Church & Prayer \\
\hline Family & Love & & Marriage \\
\hline Economy & Gain & Corporation & Transaction \\
\hline Politics & General interest & State & Voting \\
\hline Play & Fun & Gallery & Game \\
\hline Knowledge & Curiosity & University & Experiment \\
\hline Military & Honour & Army & Drill \\
\hline Law & Justice & Court & Pleading \\
\hline
\end{tabular}

${ }^{1}$ Tyburn being the place of execution in London 